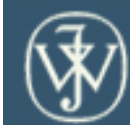

WILEY

Journal of Experimental Zoology Part A:

Ecological Genetics and Physiology

\title{
Haematological Responses of the Grey Carpet Shark (Chiloscyllium punctatum) and the Epaulette Shark (Hemiscyllium ocellatum) to Anoxia and Re-oxygenation Exposure.
}

\begin{tabular}{|c|c|}
\hline Journal: & $\begin{array}{l}\text { Journal of Experimental Zoology Part A: Ecological Genetics and } \\
\text { Physiology }\end{array}$ \\
\hline Manuscript ID: & JEZ-A-2008-09-0125.R1 \\
\hline Wiley - Manuscript type: & Research Paper \\
\hline $\begin{array}{r}\text { Date Submitted by the } \\
\text { Author: }\end{array}$ & $\mathrm{n} / \mathrm{a}$ \\
\hline Complete List of Authors: & $\begin{array}{l}\text { Chapman, Clint; Griffith University, Physiotherapy and Exercise } \\
\text { Science } \\
\text { Renshaw, Gillian; Griffith University, Physiotherapy and Exercise } \\
\text { Science }\end{array}$ \\
\hline Keywords: & $\begin{array}{l}\text { Anoxia tolerance, Re-oxygenation, Haematology, Protective } \\
\text { mechanisms }\end{array}$ \\
\hline
\end{tabular}

\section{s ScholarONE" \\ Manuscript Central}




\title{
Haematological Responses of the Grey Carpet Shark (Chiloscyllium punctatum) and the Epaulette Shark (Hemiscyllium ocellatum) to Anoxia and Re-oxygenation Exposure.
}

\author{
Authors: $\quad$ Clint A. Chapman and Gillian M.C. Renshaw* \\ Hypoxia and Ischemia Research Unit, \\ School of Physiotherapy and Exercise Science, \\ Griffith University, Gold Coast Campus, \\ Queensland, Australia 4222. \\ Pages: $\quad 38$ \\ Figures: $\quad 6$ \\ Tables: $\quad 2$
}

Abbreviated title: Haematological responses to anoxia and re-oxygenation.

*Correspondence to: Associate Professor Gillian Renshaw

Hypoxia and Ischemia Research Unit, School of Physiotherapy and Exercise Science, Griffith University, Gold Coast Campus, Queensland, Australia 4222.

Phone: 61-7-5552-8392;

Fax: 61-7-5552-8674;

Email: g.renshaw@griffith.edu.au

Key Words: Anoxia tolerance, Re-oxygenation, Haematology, Epaulette shark, Grey carpet shark, Haematocrit, Erythrocyte, Haemoglobin, Glucose, Lactate 


\begin{abstract}
We compared the haematological responses of wild and captive populations of two closely related sharks to a standardised anoxic challenge and during a 12 hour recovery period in normoxia: the epaulette shark (Hemiscyllium ocellatum, Bonnaterre, 1788) and the grey carpet shark (Chiloscyllium punctatum, Müller and Henle, 1838). Compared to normoxic controls, a significant increase in haematocrit (captive 22.3\%; wild 35.9\%) coupled with a decline in mean corpuscular haemoglobin concentration occurred in epaulette sharks indicating erythrocyte swelling in response to anoxia. However, the grey carpet shark had a significantly increased haematocrit (captive 27.2\%; wild 29.3\%), erythrocyte count (captive $37.6 \%$; wild 46.3\%) and haemoglobin concentrations (captive 31.9\%; wild $31.5 \%$ ), suggesting a release of erythrocytes into the circulation and/or haemoconcentration in response to anoxia. Plasma glucose concentrations were maintained in both wild and captive epaulette sharks and in wild grey carpet sharks during anoxia but increased significantly after 2 hours of re-oxygenation (epaulette: captive $55.8 \%$; wild $50.1 \%$; grey carpet shark: wild $70.3 \%$ ) and remained elevated for 12 hours. Captive grey carpet sharks had an immediate increase in plasma glucose concentrations after anoxia $(96.4 \%)$, which was sustained for 12 hours of re-oxygenation. Lactate concentrations significantly increased in captive and wild animals of both species after anoxia, reaching a peak at 2 hours of re-oxygenation. Both species showed significant, yet divergent, haematological changes in response to anoxia and re-oxygenation, which may not only prolong their survival and assist in recovery but also, reflect their respective ecophysiological adaptations to the extreme environments that they inhabit.
\end{abstract}




\section{INTRODUCTION}

While the tolerance of most vertebrates to low oxygen conditions is negligible, research into the comparative physiology of species encountering hypoxia and/or anoxia in their natural environment has revealed that some vertebrates have developed a repertoire of specialised adaptive strategies which prolong their tolerance to reduced oxygen conditions. In elasmobranchs, the hypoxia tolerance of the epaulette shark (Hemiscyllium ocellatum; Bonnaterre, 1788) has been well characterised (Mulvey and Renshaw, 2000); Routley et al., 2002; Soderstrom et al., '99; Wise et al., '98). During hypoxia, this species up regulates the level of anaerobic metabolism while conserving ATP usage via adaptive mechanisms such as ventilatory and metabolic depression (Routley et al., 2002), bradycardia (Soderstrom et al., '99) and neuronal hypometabolism (Mulvey and Renshaw, 2000). More recently the epaulette shark has been observed to tolerate significant periods of anoxia (Renshaw et al., 2002). It has been suggested that tolerance to low oxygen conditions in this species confers an adaptive advantage which enables the epaulette shark to remain active on sheltered coral reef platforms that are cyclically exposed to severe periods of hypoxia during nocturnal low tides (Nilsson and Renshaw, 2004; Routley et al., 2002).

The grey carpet shark (Chiloscyllium punctatum; Müller and Henle, 1838) is a close relative to the epaulette shark, residing in the family Hemiscyllidae. The grey carpet shark has a more varied distribution and is commonly found in seagrass beds, mangrove swamps as well as in tidal pools and on coral reefs (Last and Stevens, '94), however, it is not commonly found in abundance on the intermittently hypoxic reef flats inhabited by the epaulette shark. While the ability of the grey carpet shark to tolerate conditions of severely reduced oxygen saturation has not previously been examined, our preliminary experiments indicated that this 
species may also have the capacity to tolerate prolonged periods of anoxia. We examined the haematological response of these two closely related sharks to anoxia followed by reoxygenation in normoxia in order to determine whether changes in haematological profiles reflect the ecophysiology of each population.

It is well known that haematological modifications can provide significant advantages in reducing cellular stress and prolonging survival in a range of vertebrates (Affonso et al., 2002; Soldatov, '96; Soivio et al., '74; Richmond et al., 2005). Changes in haematological measures such as haematocrit, erythrocyte (RBC) number and haemoglobin concentrations in response to hypoxia have been well characterised in teleost fishes (Affonso et al., 2002; Baker et al., 2005; Pearson and Stevens, '91; Soivio et al., '74; Yamamoto, '87; Yamamoto et al., '83), although a more severe stress, such as anoxia has had little attention. Such adaptive haematological changes have been attributed to a number of different mechanisms, such as fluid shifts out of the blood plasma (Kirk, '74; Hall et al., '26; Swift and Loyd, '74), cell swelling (Soivio et al., '74a, b) and the release of RBCs into the circulating blood from storage organs, such as the spleen (Lai et al., 2006; Pearson and Stevens, '91; Yamamoto et al., '83; Yamamoto, '87). Interestingly, no significant differences in haematocrit and RBC concentrations were observed following hypoxia in the epaulette shark (Routley et al., 2002), the spotted dogfish (Scyliorhinus canicula) (Butler et al., '79) or the bonnethead shark (Sphyrna tiburo) (Carlson and Parson, 2003), however elasmobranch haematological responses to an anoxic insult had not previously been examined.

Increases in plasma lactate during reduced oxygen conditions are a stereotypical response to an increase in anaerobic metabolism. These increases have been observed following cyclic, acute and progressive hypoxia in elasmobranchs such as the epaulette shark 
(Mulvey and Renshaw, 2000; Routley et al., 2002; Wise et al., '98) and the electric ray (Torpedo marmorata) (Hughes and Johnston, '78), with the increased levels being similar to those observed in hypoxia exposed intolerant teleost fishes (Virani and Rees, 2000; Wells and Baldwin, 2006).

Up-regulation of anaerobic metabolism during anoxia consumes significantly larger quantities of plasma glucose. Elevated plasma glucose concentrations have been reported in anoxia-tolerant vertebrates such as Chrysemys turtles, the crucian carp (Carcassius carassius) and in anoxia intolerant teleosts, to fuel the increases in anaerobic metabolism (Lutz and Nilsson, '97; McDonald and Milligan, '92). No changes in plasma glucose concentrations have been observed during hypoxic exposure in either the spotted dogfish ( $S$. canicula) (Butler et al. '79) or the epaulette shark (Routley et al., 2002).

Results from previous studies concluded that elasmobranchs, in general, may not possess the ability to alter their haematology or plasma glucose concentrations in response to hypoxia or anoxia, a capacity which may be evolutionarily reserved to higher vertebrates (Lutz and Nilsson, '97). However previous studies on hypoxia-intolerant elasmobranchs and the anoxia-tolerant epaulette shark have only investigated the changes in the blood constituents in response to hypoxic challenges. This is the first study to examine the haematological responses of two elasmobranch species to prolonged anoxic exposure followed by re-oxygenation in normoxia.

In general, studies of hypoxia- and anoxia-tolerance have only investigated animals from either wild or captive populations. The hypoxic and anoxic response of the epaulette shark has only been examined in animals caught from their natural environment on coral reef 
flats. Within these environments, animals are periodically exposed to increasingly severe periods of hypoxia and it is possible that the anoxia tolerance of this species is enhanced by pre-conditioning as a result of cyclic exposure to hypoxia in their natural environment (Nilsson and Renshaw, 2004 review; Routley et al., 2002). Renshaw et al. (2002) observed a pre-emptive induction of hypometabolism due to pre-conditioning 24 hours after an initial anoxic challenge. Since animals raised in a captive environment with a constant oxygen supply have not been pre-exposed to such pre-conditioning events, they provide a useful comparison to the responses of wild sharks that are often exposed to cyclic pre-conditioning provided by the epaulette shark's natural reef environment. Therefore, the haematological responses to anoxia were examined in animals caught from the wild and compared with those of animals kept under constant environmental conditions in commercial aquaria.

The comparative investigation of hypoxia- and anoxia-tolerant animals offers an enormous potential to provide an understanding of the underlying mechanisms involved in the diverse array of strategies that specialised vertebrates have evolved to deal with oxygen deprivation. This study examined the response of haematocrit, haemoglobin concentrations, erythrocytes, plasma glucose and lactate levels of the epaulette shark and grey carpet shark to a standardised anoxic challenge followed by re-oxygenation in both captive and wild populations. 


\section{MATERIALS AND METHODS}

\section{Study animals and locations}

Captive epaulette sharks $(n=9)$ and grey carpet sharks $(n=9)$ were supplied by, UnderWater World (Mooloolaba, Sunshine Coast) and Sea World (Main Beach, Gold Coast) and the experiments were carried out on site. Epaulette sharks held in captivity were supplied from an accredited commercial collector in the previous year had a mean length of $71.58 \pm$ $7.13 \mathrm{~cm}$ and weight of $1.43 \pm 0.36 \mathrm{~kg}$. Grey carpet sharks were born in captivity 2 years earlier and had a mean length of $88.56^{ \pm} 8.12 \mathrm{~cm}$ and weight of $2.94{ }^{ \pm} 0.84 \mathrm{~kg}$. Both species were kept in a constant seawater flow-through aquarium with a normal photoperiod and no additional light sources in their outside habitats.

Wild epaulette sharks $(n=10)$ were collected from Heron Island in the Capricorn bunker group (latitude $23^{\circ} 27^{\prime} \mathrm{S}$, longitude $151^{\circ} 55^{\prime}$ E) (GBRMPA Permit \# GO4/12675.1) and the experiments were conducted at the Heron Island Research Station. Wild epaulette sharks had a mean length of $61.77^{ \pm} 3.56 \mathrm{~cm}$ and weight of $0.55^{ \pm} 0.12 \mathrm{~kg}$. Wild grey carpet sharks ( $n=6$ ) were caught in Moreton Bay (latitude $27^{\circ} 28^{\prime} \mathrm{S}$, longitude $153^{\circ} 23^{\prime} \mathrm{E}$ ) (DPI and Fisheries Permit \#PRM38182I) and experiments were conducted at the Moreton Bay Research Station. Wild grey carpet sharks had a mean length of $92.62{ }^{ \pm} 5.51 \mathrm{~cm}$ and weight of $2.73 \pm 0.47 \mathrm{~kg}$. For both wild epaulette sharks and grey carpet sharks, experiments were conducted 24 hours following capture, to allow sufficient time for the ventilatory rate, an indication of stress levels, to return to normal without allowing time for potentially significant changes in biochemical adaptation to captivity. Both captive and wild animals were acclimated in ambient oceanic seawater at $24^{\circ} \mathrm{C}$ at their respective sites. Food was 
withheld in both captive and wild animals, for 24 hours before the first blood samples were taken at the commencement of the experiment.

\section{Anoxic Challenge and Re-oxygenation}

Individual animals were exposed to 1.5 hours of anoxia (experimental groups) or normoxia (normoxic transfer-1 for control groups) in $70 \mathrm{~L}$ glass tanks, followed by 12 hours of re-oxygenation after transfer to a separate $200 \mathrm{~L}$ normoxic tank at $24^{\circ} \mathrm{C}$, re-oxygenation for anoxic treated animals and normoxic transfer- 2 for controls. All sharks were maintained in a fasted state. Each treatment tank was filled with normoxic seawater and sealed with plastic wrap and a Perspex lid. Seawater was circulated around the tank using a submersible 228-power head pump (CCC Pty. Ltd., Sydney, New South Wales, Australia) to ensure uniform conditions throughout. In the anoxic tanks, nitrogen gas was bubbled through an air stone to displace dissolved oxygen. The dissolved oxygen concentration $\left[\mathrm{dO}_{2}\right]$ levels were measured and recorded each minute using TPS WP-90 oxygen probes (TPS Pty. Ltd., Brisbane, Queensland, Australia). In the anoxic tank the $\left[\mathrm{dO}_{2}\right]$ was maintained below 0.02 $m g \mathrm{~L}^{-1}$. In the normoxic tanks, air was bubbled through an air stone to maintain the $\left[\mathrm{dO}_{2}\right]$ above $7.0 \mathrm{mg} \mathrm{L}^{-1}$. Anoxic conditions were maintained within each tank by the moderate adjustment of nitrogen injection into the tank water using brass gange valves. Animals were closely pair-matched for length and one member from each pair was randomly selected for either anoxic exposure or the normoxic control treatment. Animals were weighed and measured at the conclusion of the experiment. 


\section{Blood Sampling and Haematology}

Blood samples were taken rapidly from un-anaesthetised fish immediately prior to the beginning of the experiment $\left(\mathrm{t}_{0}\right)$ to provide a pre-experimental measurement for each haematological parameter. A $1.5 \mathrm{ml}$ blood sample was taken from the dorsal aorta of each animal using a heparinised syringe via the venipuncture method described in Stoskopf et al. ('84). Blood samples were then transferred to $3 \mathrm{ml}$ lithium heparin vacutainers (Becton Dickinson, North Ridge, New South Wales, Australia) and gently mixed. Additional blood samples were collected immediately following control or experimental treatment (post-/ $t_{1.5}$ ) then after 2 hours $\left(t_{2}\right), 6$ hours $\left(t_{6}\right)$ and 12 hours $\left(t_{12}\right)$ of re-oxygenation in normoxia after anoxic challenge or after normoxic transfer- 2 for controls.

Haematocrit was determined using heparinised haematocrit microtubes and centrifuged at $2500 \mathrm{rpm}$ for 5 minutes at $4^{\circ} \mathrm{C}$ in an Eppendorf $5415 \mathrm{D}$ centrifuge. Haematocrit values were determined against a micro-haematocrit grid (Sigma-Aldrich, Newcastle, New South Wales, Australia). Red blood cell (RBC) concentrations [RBC] were calculated via haemocytometry cell counts using a Neaubaur counting chamber. Blood samples were diluted 1:200 in chilled phosphate buffered saline ( $\mathrm{pH} 7.2)$ and vortexed gently. The diluted solution $(5 \mu \mathrm{l})$ was loaded into the Neaubaur counting chamber and examined under $10 \mathrm{x}$ magnifications using a compound light microscope. Blood haemoglobin was determined in triplicate, by a cyanmethaemoglobin technique using modified Drabkin's Reagent (SigmaAldrich, Newcastle, New South Wales, Australia). One millilitre of Drabkin's reagent and 4 $\mu \mathrm{l}$ of blood were placed into a $1.6 \mathrm{ml}$ cuvette and vortexed gently. Samples were incubated in the dark, at room temperature for 15 minutes before being analysed using a UV Mini 1240 spectrophotometer (Shimadzu, Suzhoa, Republic of China) at a wavelength of $540 \mathrm{~nm}$. 
Sample haemoglobin concentrations were compared against a haemoglobin standard curve using the human haemoglobin standard supplied by Sigma-Aldrich (Newcastle, New South Wales, Australia).

The RBC indices calculated were: the mean corpuscular volume (MCV), mean corpuscular haemoglobin $(\mathrm{MCH})$, mean corpuscular haemoglobin concentration (MCHC), haematocrit levels and haemoglobin concentrations. The formulae of Stoskopf ('93) were used as follows:

$\mathrm{MCV}=(\mathrm{Hct} /[\mathrm{RBC}]) \times 10$,

$\mathrm{MCH}=(\mathrm{Hb} \times 10) /[\mathrm{RBC}]$, and

$\mathrm{MCHC}=(\mathrm{Hb} \times 100) /$ Hct.

Blood plasma was separated from a $0.5 \mathrm{ml}$ blood sample after it was centrifuged at $3000 \mathrm{rpm}$ for 3 minutes at $4^{\circ} \mathrm{C}$ then frozen at $-80^{\circ} \mathrm{C}$ for later use. Plasma glucose concentrations were determined using a colorimetric glucose hexokinase assay kit (SigmaAldrich, Newcastle, New South Wales, Australia) following the manufacturer's directions and read at a wavelength of $340 \mathrm{~nm}$. Briefly, cuvettes containing a 1:500 dilution of plasma to glucose reagent were gently vortexed and incubated at room temperature for 15 minutes before colorimetric analysis. Sample plasma glucose concentrations were compared against a glucose standard curve using the glucose standard solution supplied by Sigma-Aldrich (Newcastle, New South Wales, Australia).

Plasma lactate concentrations were determined using a colorimetric Lactate Assay kit (Immuno Diagnostics, St. Peters, New South Wales, Australia) following the manufacturer's directions and read at a wavelength of $540 \mathrm{~nm}$. Cuvettes containing a 1:100 dilution of 
plasma to lactate reagent were gently vortexed and incubated at room temperature for 5-10 minutes before colorimetric analysis. Sample plasma lactate concentrations were compared against a lactate standard curve, using the lactate standard solution supplied by Immuno Diagnostics (St Peters, New South Wales, Australia).

\section{Statistics}

The data was analysed using a Mixed Model Repeated Measures ANOVA so that we could test the main effects and interaction effects of: sample time, population type (wild or captive) and treatment (experiment or normoxic control), followed by a post-hoc Bonferroni adjustment. The alpha level was set at 0.05 . The data and error bars are represented as mean \pm standard deviation.

\section{RESULTS}

\section{Haematocrit}

For epaulette sharks, the mean haematocrit values prior to any treatment (preexperimental) were similar for captive $\left(\mathrm{t}_{0}=19^{ \pm} 1.4 \%\right)$ and wild $\left(\mathrm{t}_{0}=22.8^{ \pm} 2.8 \%\right)$ animals irrespective of whether they were in control or experimental groups (Figure 1A and 1B). However, there was a main effect of environment for the grey carpet shark, the mean haematocrit values prior to any treatment were significantly higher $(p<0.01)$ in the in wild animal group $\left(\mathrm{t}_{0}=27.3^{ \pm} 2.2 \%\right)$ than the captive animal group $\left(\mathrm{t}_{0}=20.9^{ \pm} 2.5 \%\right),($ Figure $1 \mathrm{~A})$. No significant differences were observed in pre-experimental mean haematocrit values of either captive or wild grey carpet sharks allocated to the anoxic challenge group compared to 
their respective control groups (Figure 1B). Furthermore, in the normoxic control groups, there were no significant changes in mean haematocrit values in captive or wild animals for either epaulette sharks or grey carpet sharks at any time points compared to their preexperimental values, irrespective of sample time (Figure 1A).

Immediately following 1.5 hours of anoxic exposure there was a main effect of sample time. Captive and wild epaulette sharks had a significant increase in the mean haematocrit value (captive, $\mathrm{t}_{1.5}=23.2^{ \pm} 1.6 \%$; wild, $\mathrm{t}_{1.5}=30.9^{ \pm} 2.4 \%$ ) above the preexperimental mean measure $(p<0.01)$, which remained at this elevated plateau for up to 2 hours following re-oxygenation (Figure 1B). Similarly in the grey carpet shark, mean haematocrit values increased significantly from pre-experimental mean values $(p<0.001)$, immediately following 1.5 hours of anoxia in both captive $\left(\mathrm{t}_{1.5}=26.6^{ \pm} 1.5 \%\right)$ and wild $\left(\mathrm{t}_{1.5}=\right.$ $35.3^{ \pm} 2.1 \%$ ) animals and remained at this elevated plateau for up to 2 hours following reoxygenation (Figure 1B). After 6 hours normoxic re-oxygenation, mean haematocrit values in wild and captive epaulette sharks as well as grey carpet sharks returned to pre-experimental values and remained there for an additional 6 hours (Figure 1B). There were also interactions with the environmental source of the sharks sampled: wild epaulette sharks had significantly higher haematocrit values at the post-anoxia sample point than did captive epaulette sharks $(p<0.001)$ (Figure 1B). However after 2 hours of re-oxygenation, there were no significant differences in mean haematocrit values between captive and wild epaulette sharks. Wild grey carpet sharks also had significantly higher haematocrit values from captive animals after anoxic exposure and after 2 hours of re-oxygenation. 


\section{Red blood cell count}

The mean $[\mathrm{RBC}]$ of control animals in either species did not change significantly during the sample time course, data not shown. In the experimental groups, mean [RBC] prior to treatment revealed no significant differences in captive and wild epaulette shark (captive, $\mathrm{t}_{0}=0.34 \pm 0.06 \times 10^{-6} \mathrm{uL}^{-1}$; wild, $\mathrm{t}_{0}=0.34^{ \pm} 0.04 \times 10^{-6} \mathrm{uL}^{-1}$ ) or grey carpet sharks (captive, $\mathrm{t}_{0}=0.31^{ \pm} 0.007 \times 10^{-6} \mathrm{uL}^{-1}$; wild, $\mathrm{t}_{0}=0.3^{ \pm} 0.03 \times 10^{-6} \mathrm{uL}^{-1}$ ) (Figure 2). There was an interaction of species by sample time in response to anoxic challenge followed by reoxygenation. In epaulette sharks, there were no significant changes in mean [RBC] in captive or wild epaulette sharks immediately following 1.5 hours of anoxia or throughout the 12 hours of normoxic re-oxygenation (Figure 2) when compared to pre-experimental mean concentrations. Conversely grey carpet sharks responded to anoxia with a significant increase in $[\mathrm{RBC}]$ in captive animals and wild animals (captive, $\mathrm{t}_{1.5}=0.43^{ \pm} 0.03 \times 10^{-6} \mathrm{uL}^{-1}$; wild, $\mathrm{t}_{1.5}$ $=0.3 \pm 0.03 \times 10^{-6} \mathrm{uL}^{-1}$ ) from their respective pre-experimental mean concentrations $(\mathrm{p}<0.001)$. Mean $[\mathrm{RBC}]$ remained elevated at this plateau for 2 hours following reoxygenation and then returned back to pre-experimental concentrations by 6 hours of normoxic re-oxygenation (Figure 2). Mean [RBC] remained at pre-experimental concentrations throughout the remainder of the experiment (12 hours of normoxic reoxygenation). These results paralleled the significance patterns observed in the haematocrit measures described above and in haemoglobin concentration described below.

\section{Haemoglobin}

Prior to the commencement of the experiment, epaulette sharks from the wild population had significantly higher haemoglobin concentrations $\left(t_{0}=6.24{ }^{ \pm} 0.4 \mathrm{~g} \mathrm{dL}^{-1}\right)$ than 
captive animals $\left(\mathrm{t}_{0}=5.34^{ \pm} 0.4 \mathrm{~g} \mathrm{dL}^{-1}\right)$ (Figure $\left.3 \mathrm{~A}\right)$. Similarly, the wild grey carpet sharks had significantly higher mean haemoglobin concentrations $\left(\mathrm{t}_{0}=7.5^{ \pm} 0.5 \mathrm{~g} \mathrm{dL}{ }^{-1}\right)$ than captive grey carpet sharks $\left(\mathrm{t}_{0}=6.27^{ \pm} 0.5 \mathrm{~g} \mathrm{dL}^{-1}\right)$ prior to the commencement of the experiment $(\mathrm{p}<0.05)$ (Figure 3A).

Throughout the remainder of the normoxic (control) sampling regime, neither epaulette sharks nor grey carpet sharks from either wild or captive populations showed any significant differences in mean haemoglobin concentrations from their respective initial mean concentrations (Figure 3A). With regard to haemoglobin concentration there was a two way interaction of species by time. The mean haemoglobin concentrations of wild and captive epaulette sharks exposed to an anoxic challenge followed by re-oxygenation, did not significantly change from pre-experimental mean concentrations at either the post-anoxia sample point or during the 12 hours of normoxic re-oxygenation (Figure 3B). In contrast, captive and wild grey carpet sharks had a significant increase in haemoglobin concentrations (captive, $\mathrm{t}_{0}=6.27{ }^{ \pm} 0.5 \mathrm{~g} \mathrm{dL}^{-1} ; \mathrm{t}_{1.5}=8.27^{ \pm} 0.6 \mathrm{~g} \mathrm{dL}^{-1}$; wild, $\mathrm{t}_{0}=7.5^{ \pm} 0.5 \mathrm{~g} \mathrm{dL}^{-1} ; \mathrm{t}_{1.5}=9.86^{ \pm}$ $\left.0.4 \mathrm{~g} \mathrm{dL}^{-1}\right)$ immediately following anoxia treatment $(\mathrm{p}<0.001)$, which remained elevated at this plateau for at least 2 hours of normoxic re-oxygenation (Figure 3B). Furthermore, wild grey carpet sharks had significantly higher haemoglobin concentrations than captive animals, immediately after anoxia and following 2 hours of normoxic re-oxygenation $(p<0.001)$. In both captive and wild grey carpet sharks, mean haemoglobin concentrations had returned to pre-experimental concentrations by 6 hours of normoxic re-oxygenation, and remained at these concentrations until the last sample point at 12 hours of re-oxygenation. 


\section{Calculated erythrocytic indices}

There were no significant differences in calculated RBC indices between untreated captive and wild epaulette sharks at pre-experimental mean levels (Table 1). However wild and captive epaulette sharks showed a significant increase in mean corpuscular volume (MCV) immediately following anoxic exposure $(\mathrm{p}<0.001)$, which remained elevated for the first 2 hours of normoxic re-oxygenation before returning back to pre-experimental levels by 6 hours of normoxic re-oxygenation. Conversely, a significant decrease in mean corpuscular haemoglobin concentration (MCHC) occurred immediately following anoxia and for 2 hours of normoxic re-oxygenation in both wild $(\mathrm{p}<0.001)$ and captive $(\mathrm{p}<0.01)$ epaulette sharks, before returning back to pre-experimental levels. These significant differences were not evident when $[\mathrm{RBC}]$ rather than haematocrit was used in the calculations to obtain mean corpuscular haemoglobin $(\mathrm{MCH})($ Table 1$)$.

No significant differences in any of the RBC indices were observed in untreated captive or wild grey carpet sharks (Table 2) nor in wild and captive grey carpet sharks after 1.5 hours of anoxia and up to 12 hours of normoxic re-oxygenation (Table 2).

\section{Glucose}

There was a significant main effect of species. Post-anoxic challenge, the grey carpet sharks had higher plasma glucose concentrations than did epaulette sharks. This was clarified further by examining the interaction of species, sample time and population type. Throughout the control regime, epaulette sharks (wild and captive) and grey carpet sharks (wild and captive) showed no significant differences in mean plasma glucose concentrations from their 
respective pre-experimental mean concentrations (data not shown). The mean plasma glucose concentrations in epaulette sharks and the grey carpet shark prior to treatment were not significantly different between captive (epaulette shark, $\mathrm{t}_{0}=0.55^{ \pm} 0.04 \mathrm{mg} \mathrm{dL}^{-1}$; grey carpet shark, $\mathrm{t}_{0}=0.68 \pm 0.04 \mathrm{mg} \mathrm{dL}^{-1}$ ) or wild sharks (epaulette shark, $\mathrm{t}_{0}=0.6^{ \pm} 0.08 \mathrm{mg} \mathrm{dL}^{-1}$; grey carpet sharks, $\mathrm{t}_{0}=0.67 \pm 0.06 \mathrm{mg} \mathrm{dL}^{-1}$ ) nor in the pre-experimental levels of sharks allocated to anoxic or normoxic groups (Figure 4).

While the response pattern was similar for both species, the grey carpet sharks responded with a plasma glucose level of a higher magnitude. Immediately following anoxic exposure, no significant differences were observed in mean plasma glucose concentrations in captive $\left(\mathrm{t}_{1.5}=0.64{ }^{ \pm} 0.09 \mathrm{mg} \mathrm{dL}-1\right)$ and wild $\left(\mathrm{t}_{1.5}=0.72 \pm 0.1 \mathrm{mg} \mathrm{dL}^{-1}\right)$ epaulette sharks or in the wild grey carpet sharks $\left(\mathrm{t}_{1.5}=0.77 \pm 0.09 \mathrm{mg} \mathrm{dL}^{-1}\right)$ compared to their pre-experimental mean concentrations (Figure 4). However, after 2 hours of re-oxygenation, mean plasma glucose concentrations significantly increased in both captive $\left(\mathrm{t}_{2}=0.85^{ \pm} 0.09 \mathrm{mg} \mathrm{dL}^{-1}\right)$ and wild $\left(\mathrm{t}_{2}=0.9^{ \pm} 0.13 \mathrm{mg} \mathrm{dL}{ }^{-1}\right)$ epaulette sharks $(\mathrm{p}<0.01)$ compared to pre-experimental concentrations and remained at this elevated plateau throughout the 12 hours of reoxygenation. However in captive grey carpet sharks had significant increase mean plasma glucose above pre-experimental levels immediately post-anoxia $\left(\mathrm{t}_{1.5}=1.36 \pm 0.09 \mathrm{mg} \mathrm{dL} \mathrm{dL}^{-1}\right)$ $(\mathrm{p}<0.001)$. The mean plasma glucose concentrations of captive grey carpet sharks remained at this elevated plateau for up to 12 hours of re-oxygenation.

A further interaction occurred between species, sample time and population revealing that only the captive grey carpet sharks had an immediate elevation in plasma glucose levels post-anoxia (Figure 4). In wild grey carpet sharks, the mean plasma glucose concentrations 
increased by a significantly greater magnitude than the epaulette shark at 2 hours of reoxygenation $\left(\mathrm{t}_{2}=1.14^{ \pm} 0.02 \mathrm{mg} \mathrm{mL} L^{-1}\right)(\mathrm{p}<0.001)$.

\section{Lactate}

In control animals, captive and wild epaulette sharks, along with captive grey carpet sharks, showed a significant increase in mean plasma lactate concentrations with a main effect of species (captive epaulette shark, $\mathrm{t}_{1.5}=121.3^{ \pm} 31.9 \mathrm{mg} \mathrm{dL}^{-1}$; wild epaulette shark, $\mathrm{t}_{1.5}$ $=145.8 \pm 37.3 \mathrm{mg} \mathrm{dL}^{-1}$; captive grey carpet shark, $\mathrm{t}_{1.5}=71.9^{ \pm} 52.2 \mathrm{mg} \mathrm{dL}^{-1}$ ) immediately following 1.5 hours of confinement in the control aquaria $(\mathrm{p}<0.001)$ (Figure 5A). Control groups of epaulette sharks had significantly higher plasma lactate levels than grey carpet sharks until 12 hours post-transfer. In both wild and captive epaulette sharks, mean plasma lactate concentrations were sustained at an elevated plateau for 2 hours after transfer-2, to a normoxic tank, as a control for normoxic re-oxygenation. Mean plasma lactate concentrations had returned back to mean pre-experimental concentrations 2 hours after transfer-2, in the captive grey carpet shark or 6 hours after transfer 2 in the captive and wild epaulette sharks.

The pre-experimental mean plasma lactate concentrations in epaulette sharks was significantly higher in captive animals $\left(\mathrm{t}_{0}=31.2^{ \pm} 13.4 \mathrm{mg} \mathrm{dL}^{-1}\right)$ than in wild animals $\left(\mathrm{t}_{0}=2.3\right.$ $\left.{ }^{ \pm} 0.5 \mathrm{mg} \mathrm{dL}^{-1}\right)(\mathrm{p}<0.001)$ (Figure 5A). However, a main effect of sample time was evident in response to 1.5 hours of anoxia: epaulette sharks (captive and wild) had significant increases in mean plasma lactate concentrations immediately following anoxia (captive, $\mathrm{t}_{1.5}=254.1 \pm$ $22.8 \mathrm{mg} \mathrm{dL}{ }^{-1}$; wild, $\left.\mathrm{t}_{1.5}=242.1 \pm 16.1 \mathrm{mg} \mathrm{dL}^{-1}\right)(\mathrm{p}<0.001)$ (Figure 5B). By 2 hours of normoxic re-oxygenation, mean plasma lactate concentrations continued to increase from pre-experimental concentrations (captive, $\mathrm{t}_{2}=472.9^{ \pm} 37.3 \mathrm{mg} \mathrm{dL}{ }^{-1}$; wild, $\mathrm{t}_{2}=359.6^{ \pm} 43.2 \mathrm{mg}$ 
$\left.\mathrm{dL}^{-1}\right)(\mathrm{p}<0.001)$. Epaulette sharks maintained these elevated concentrations for at least 6 hours of normoxic re-oxygenation. By 12 hours of normoxic re-oxygenation plasma lactate concentrations had returned to $225.1 \pm 28.5 \mathrm{mg} \mathrm{dL}^{-1}$ in captive animals and $59{ }^{ \pm} 43.3 \mathrm{mg} \mathrm{dL}^{-1}$ in wild animals.

Pre-experimental mean plasma lactate concentrations in grey carpet sharks were not significantly different between captive $\left(\mathrm{t}_{0}=2.5^{ \pm} 0.9 \mathrm{mg} \mathrm{dL}{ }^{-1}\right)$ and wild $\left(\mathrm{t}_{0}=3.5^{ \pm} 2.3 \mathrm{mg} \mathrm{dL}{ }^{1}\right)$ animals irrespective of whether they had been allocated to normoxic control groups or anoxia treatment groups (Figure 5A and B). The main effect of sample time was evident immediately following 1.5 hours of anoxia, both captive and wild grey carpet sharks had significant increases in mean plasma lactate concentrations post anoxic challenge (captive, $\mathrm{t}_{1.5}$ $=166.9^{ \pm} 41 \mathrm{mg} \mathrm{dL}^{-1}$; wild, $\left.\mathrm{t}_{1.5}=139.3^{ \pm} 34.8 \mathrm{mg} \mathrm{dL}^{-1}\right)(\mathrm{p}<0.001)$. In wild grey carpet sharks, the mean plasma lactate concentrations were sustained at this elevated plateau for up to 6 hours of re-oxygenation (wild, $\mathrm{t}_{6}=197.2^{ \pm} 29 \mathrm{mg} \mathrm{dL}^{-1}$ ), while captive grey carpet sharks had an additional significant increase in plasma lactate levels after 2 hours of re-oxygenation (captive, $\mathrm{t}_{2}=299.1 \pm 86.1 \mathrm{mg} \mathrm{dL}^{-1}$ ) and remained at this elevated concentration for up to 6 hours of re-oxygenation. By 12 hours of re-oxygenation, mean plasma lactate concentrations in the captive and wild grey carpet shark had significantly declined $(p<0.001)$, yet they were still significantly elevated above pre-experimental concentrations (captive, $\mathrm{t}_{12}=59.1 \mathrm{mg} \pm$ $16.9 \mathrm{dL}^{-1}$; wild, $\left.92.1 \pm 40.7 \mathrm{mg} \mathrm{dL}^{-1}\right)(\mathrm{p}<0.001)$. 


\section{DISCUSSION}

\section{Haematological differences in control animals from captive and wild populations of two species of shark.}

Wild epaulette sharks as well as grey carpet sharks are intermittently exposed to hypoxia in their natural environment while captive sharks at Underwater World or Sea World do not experience hypoxia. The mean haematocrit values and $[\mathrm{RBC}]$ were similar for captive and wild epaulette sharks in control groups prior to any treatment. However the haemoglobin concentration in the wild epaulette sharks was significantly higher. Perhaps wild epaulette sharks maintain higher haemoglobin levels in response to intermittent hypoxic challenge.

In grey carpet sharks, both the mean percentage haematocrit and haemoglobin concentration were significantly higher in animals caught in the wild, it is possible that this haematologically responsive species could have been exposed to the preconditioning effects of low oxygen in their natural environment prior to capture. Last and Stephens ('94) reported that this species can survive out of water for extended periods of time in habitats associated with tidal pools and coral reefs. We have also observed this species in the intertidal zone associated with mangroves. The physiological compensation for such extreme challenges has direct ecological relevance. If, for example the physiological response of the grey carpet shark to a sudden stranding or decrease in ambient oxygen involves releasing a pool of oxygenated red blood cells then oxygen delivery would receive a temporary boost. 


\section{Haematological responses to anoxic challenge and re-oxygenation}

While $[\mathrm{RBC}]$ for epaulette sharks were within the range previously reported by Baldwin and Wells ('90), both the percentage haematocrit and haemoglobin concentrations were higher. Such variations may be due to seasonality, animal location and/or the effect of confinement and handling stress. Routley et al. (2002) reported no changes in haematocrit levels in response to progressive hypoxia in the epaulette shark, however anoxic exposure and at 2 hours re-oxygenation in the epaulette shark in the present study resulted in a significant increased in haematocrit. The RBC size (calculated by $\mathrm{MCV}$ ), significantly increased in both captive and wild epaulette sharks, while the calculated MCHC decreased and no changes in $[\mathrm{RBC}]$ or haemoglobin concentrations were observed. Taken together these data indicate that, in the epaulette shark, an increase in RBC volume occurred immediately following anoxia and was still elevated at 2 hours of re-oxygenation. It is generally accepted that such cell swelling occurs in response to reduced oxygen conditions is predominantly attributed to either a loss of $\mathrm{Na}^{+} / \mathrm{K}^{+}$ATPase channel function, as ATP levels are depleted and/or a fall in extracellular $\mathrm{pH}$, leading to the accumulation of intracellular sodium. In teleost fishes, reduced extracellular $\mathrm{pH}$ and $\mathrm{PO}_{2}$ cause a catecholamine-induced activation of $\beta$-adrenergic $\mathrm{Na}^{+} / \mathrm{H}^{+}$exchangers in the $\mathrm{RBC}$ membrane (Fievet et al., '87). The activation of $\mathrm{Na}^{+} / \mathrm{H}^{+}$exchangers removes $\mathrm{H}^{+}$from the $\mathrm{RBC}$ in exchange for extracellular sodium. This influx of sodium is followed by chloride, which causes an osmotic influx of water, effectively alkalizing the intracellular space and resulting in cell swelling (Chiocchia and Motais, '89; Fievet et al., '87; Salama and Nikinmaa, '90).

Such increases in cell volume have been well characterised in response to reduced oxygen conditions in teleost fishes (Chiocchia and Motais, '89; Fievet et al., '87; Salama and 
Nikinmaa, '90). Although, both Tufts and Randall ('89) and Wood et al. ('94) reported the absence of a detectable $\beta$-adrenergic $\mathrm{Na}^{+} / \mathrm{H}^{+}$exchanger in the anoxia-intolerant dogfish (Squalus canicula). However the presence and activation of $\mathrm{H}^{+} / \mathrm{Na}^{+}$exchangers in an anoxiatolerant elasmobranch such as the epaulette shark has not been examined.

During hypoxia and anoxia, the accumulation of anaerobic metabolites such as lactate and $\mathrm{H}^{+}$can also be responsible for a decrease in extracellular $\mathrm{pH}$ (Jensen, 2004). In the present study, increases in RBC volume in the epaulette shark, remained elevated at peak levels for 2 hours following anoxia and returned to normal by 6 hours of re-oxygenation in normoxia. Blood lactate concentrations were significantly higher in the epaulette shark than the lactate levels responsible for inducing $\mathrm{RBC}$ swelling in teleosts such as rainbow trout (Oncorhynchus mykiss), (Salmo gairdneri) and sea bass (Morone labrax) (Soivio et al., '80; Thomas and Hughes, '82a and '82b; Thomas et al., '86). Therefore this significant increase in lactate concentrations in the epaulette shark may reflect an extracellular acidosis, which in turn could result in increases in $\mathrm{RBC}$ volume. Interestingly however a reduction in $\mathrm{RBC}$ volume occurred during re-oxygenation, when ambient oxygen levels were restored to normal, even though plasma lactate concentrations remained elevated. These data suggest that once oxygen is restored, oxygen dependent mechanisms counteract RBC swelling (Renshaw and Nikinmaa, 2007, review).

Cell swelling also occurs in response to ATP depletion, resulting in a loss of ion homeostasis (Tetens and Lykkeboe, ' 81 ). Erythrocyte ATP depletion causes a loss of $\mathrm{Na}^{+} / \mathrm{K}^{+}$ channel function, leading to the accumulation of intracellular sodium and subsequent cell swelling. While many authors have discussed the interaction between organo-phosphates and haemoglobin-oxygen binding affinity (Smit and Hattingh, 2003; Wells et al., 2005), 
controversy over the erythrocyte organo-phosphate concentrations in response to low oxygen conditions exists among different vertebrates. While changes in erythrocyte ATP levels in response to anoxia have not been examined in this species, depleting erythrocytic ATP concentrations may be responsible for increased $\mathrm{RBC}$ volume as a result of a slow loss in ion homeostasis of the RBC, which is reversed by re-oxygenation.

In contrast to the epaulette shark, no evidence of RBC swelling occurred in the grey carpet shark. Plasma lactate levels rose significantly in grey carpet sharks from both captive and wild populations but did not reach the high levels attained in the epaulette shark. However, there were significant increases in haematocrit, as well as in [RBC] and haemoglobin concentrations in both wild and captive grey carpet sharks immediately following anoxia and at 2 hours of re-oxygenation. These rapid increases in haematocrit, haemoglobin and $[\mathrm{RBC}]$ could result from the action of one or more compensatory mechanisms: a) haemoconcentration due to fluid shifts out of the plasma; b) the accelerated division and maturation of blood cells already in the circulation; c) an increase in oxygenated $[\mathrm{RBC}]$ due to their release from a storage organ such as the spleen, haemopoetic organs such as the epigonal organ and Leydig organ; d) an increase in oxygenated [RBC] due to the diversion of blood from muscles and/or the gastrointestinal tract.

Plasma volume shifts per se would not be an evolutionary advantage in low oxygen environments and since they usually occur when the ability to maintain electrolytes homeostasis is lost, one could expect that it heralds slow death rather than anoxia tolerance. The grey carpet sharks used in this study remained alive for longer than one year. While fluid shifts in response to severe hypoxia or anoxia have not been reported in elasmobranchs, Cross et al. ('69) reported that there was no change in renal function and $\mathrm{H}^{+}$excretion in 
response to hypercapnia in the dogfish (Squalus acanthias). We are currently examining electrolyte homeostasis in both the epaulette and the grey carpet shark post-anoxic challenge.

Stokes and Firkin (1971) used tritiated thymidine to show that mitosis in the systemic circulation gives rise to new thrombocytes and RBCs in the Port Jackson shark (Heterodontus portusjacksoni). It could be argued that the formation and/or accelerated maturation of RBCs could confer an ecophysiological advantage, providing that the gills remained moist. Since we observed that the $[\mathrm{RBC}]$ did return to pre-experimental values in grey carpet sharks during re-oxygenation, it seems unlikely that the elevated [RBC] observed post-anoxic challenge, occurred via mitosis in the periphery and disappeared rapidly during reoxygenation. However, if stores of oxygenated red blood cells were sequestered in storage organs and then released or if oxygenated blood was diverted from non-essential organs such as muscles and/or the gastrointestinal tract, it is conceivable that these mechanisms would have an ecophysiological relevance for grey carpet sharks experiencing diminished oxygen levels in tidal pools and estuaries. Evidence from teleost fish and some elasmobranchs suggests that the release of red blood cells via splenic contraction does occur in response to elevated catecholamines (Nilsson et al. '75).

Splenic contraction has been well characterised in teleost fishes in response to hypoxia (Lai et al., 2006; Pearson and Stevens, '91; Yamamoto et al., '83; Yamamoto, '87). Butler et al. ('79) reported no changes in RBC concentrations during hypoxia in the dogfish (S. canicula). However Nilsson et al. ('75) observed a splenic contraction in response to catecholamine and artificial nerve stimulation in both $S$. acanthias and $S$. canicula in perfused and isolated spleens. In contrast, Opdyke and Opdyke ('71) observed no release of RBC from the spleen in $S$. acanthias in response to electrical stimulation of the splenic 
pedicle or catecholamine infusion. Therefore, the function of the elasmobranch spleen to act as a RBC reservoir is currently controversial (Nilsson et al., '75; Opdyke and Opdyke, '71). However, the ability of the spleen to act as a RBC reservoir in an anoxia-tolerant elasmobranch has not been examined.

The elevated $[\mathrm{RBC}]$ in the grey carpet shark in response to anoxia could have arisen as an adaptive ecophysiologically relevant response to the low oxygen levels periodically encountered in mangrove swamps, estuaries, coral reefs and tidal pools which are part of the habitat that this species occupies. The increased [RBC] could confer increase oxygen absorption and delivery to vital organs during bouts of naturally occurring hypoxic exposure. This ability to increase $[\mathrm{RBC}]$ may also transfer an adaptive advantage during anoxia, if the haemoglobin in the RBCs is already saturated with oxygen.

\section{Glucose}

Pre- and post-experimental blood glucose concentrations in the epaulette shark and wild grey carpet sharks were not significantly higher than other shark species such as the dusky shark (Carcharhinus obscurus) and the nurse hound shark (Scyliorhinus stellaris) (Cliff and Thurman, '84; Piiper et al., '72). However, after 2 hours of re-oxygenation, plasma glucose increased significantly by $55.6 \%$ above the anoxic level in both wild and captive epaulette sharks and by $63.9 \%$ in wild grey carpet sharks, which remained elevated at these levels for at least 12 hours of re-oxygenation. Since all animals were fasted prior to and during the experiment, such increases in plasma glucose concentrations following reoxygenation suggests that glycogen stores are involved in the recovery phase, following 
anoxic exposure, in both species. A prolonged elevation in glucose levels could potentially replenish an energy debt once re-oxygenation occurred via increased aerobic metabolism.

Elevated plasma glucose concentrations are characteristic of the anoxic response in teleost fishes and higher vertebrates (Hardisty et al., '76; MacCormack et al., 2006; Wright et al., '89). However, this strategy relies on glycogen stores during reduced oxygen availability when anaerobic metabolism is the predominant source of ATP (Chippari-Gomes et al., 2005; Baker et al., 2005). In contrast, plasma glucose concentrations were maintained but not significantly elevated immediately following anoxic exposure in the wild and captive epaulette sharks or in wild grey carpet sharks.

Routley et al. (2002) observed that plasma glucose levels in wild epaulette sharks remained stable during exposure to progressive hypoxia. Current data confirmed that no changes in plasma glucose concentrations occurred in response to anoxia in either wild or captive epaulette sharks. Similarly, wild grey carpet sharks also showed no significant changes in plasma glucose concentrations immediately after anoxia. Interestingly, captive grey carpet sharks responded with a significant increase in plasma glucose concentrations immediately following anoxic exposure. Even though the pre-experimental levels of glucose were not significantly different in wild and captive grey carpet sharks it was clear that the magnitude and timing of the glucose response in captive grey carpet sharks was different than wild animals. The magnitude of the significant elevation in plasma glucose levels in response to anoxic challenge differed between the two grey carpet shark populations: after 2 hours of re-oxygenation, wild grey carpet sharks had a significant $63.9 \%$ increase while captive grey carpet sharks had a $93.5 \%$ increase from pre-experimental levels. Both populations remained at this concentration for at least 12 hours of re-oxygenation. Since normoxic control groups 
had no increases in plasma glucose concentrations due to capture or confinement, the significant increase in glucose in response to anoxia followed by re-oxygenation suggest not only that diminished oxygen may act to prime the conversion of glycogen stores to glucose in both captive and wild grey carpet sharks but also that the captive group may have had a greater response because there was a lack of natural periods of hypoxia in captive environments and/or captive grey carpet sharks may have had larger glycogen stores due to increased food availability.

Wild and captive grey carpet sharks also showed a much more pronounced increase in plasma glucose concentrations compared to epaulette sharks. These differences may be due to the magnitude of the energy debt accrued in the grey carpet shark following anoxic challenge resulting in the greater utilisation of glucose following re-oxygenation than that observed in the epaulette shark.

\section{Lactate}

In elasmobranchs, lactate concentrations rise quickly when they are exposed to acute stress such as capture and handling (Cliff and Thurman, '84; Hoffmayer and Parsons, 2001; Piiper and Baumgarten, '69; Piiper et al., '72), confinement (Martini, '74), transport (Cliff and Thurman, '84) and diminished oxygen levels (Hughes and Johnston, '78; Mulvey and Renshaw, 2000; Routley et al., 2002; Wise et al., '98). In the present study, control epaulette sharks and captive grey carpet sharks showed a significant increase in plasma lactate concentrations in response to capture, handling and confinement in a normoxic tank. These increases were most likely in response to handling and confinement as reported by Wise et al. ('98). The pre-experimental plasma lactate concentrations in captive epaulette sharks were 
significantly higher than those of wild caught epaulette sharks, in a captive environment these benthic reef sharks may have a lower activity level for two reasons: food is provided and they don't need to swim to ventilate their gills, such reduced aerobic activity could lead to lactate accumulation. This phenomenon was not observed in captive grey carpet sharks, which occupy both pelagic and benthic niches in their natural environment.

Post-anoxic challenge, epaulette shark plasma lactate concentrations peaked after 2 hours of re-oxygenation. Blood lactate concentration reached $52 \mathrm{mmol}^{-1}$ or $40 \mathrm{mmol}^{-1}$ in captive and wild epaulette sharks respectively. These values are higher than those previously reported for any other elasmobranchs. The peak lactate concentrations in grey carpet sharks were not as high (33 mmol ${ }^{-1}$ in captive and $20 \mathrm{mmol}^{-1}$ in wild sharks) as those reached in the epaulette shark and were comparable to the peak lactate concentrations, reported for other elasmobranch species in response to hypoxia (Cliff and Thurman, '84; Hoffmayer and Parsons, 2001, Piiper et al., '72). The difference between the plasma lactate response in wild and captive grey carpet sharks may indicate that anaerobic pathways were more responsive in the captive grey carpet shark and/or that the wild population had more active pathways for lactate clearance.

The high plasma lactate levels in the epaulette shark reveal that there was a significant up-regulation of anaerobic metabolism during anoxia which could be expected to prolong survival. Interestingly, both captive epaulette sharks and captive grey carpet sharks had significantly higher plasma lactate concentrations than wild animals following anoxia, revealing that anaerobic pathways were more responsive to anoxia in captive animals than in wild animals which may have been subject to natural hypoxic pre-conditioning in their own environment. Such differences between wild and captive populations may be explained by 
differences between the basal/standard aerobic metabolic rate and the maximum aerobic rate, the metabolic scope (Fry, '47), under specific conditions. In response to anoxia, captive epaulette sharks appeared to activate anaerobic pathways and accumulate lactate much earlier and at a much higher concentration than wild animals that may have already been primed by environmental exposure. In contrast, both species of captive sharks would have had prolonged acclimatisation to a stable captive environment with a constant oxygen supply. In addition, wild animals exposed to continual changes in oxygen saturation within their natural environment may require a larger metabolic scope to delay the accumulation of anaerobic end products.

Delayed peaks in plasma lactate concentrations in both the epaulette shark and the grey carpet shark following anoxia, were similar to those observed in the sharpnose shark (Rhizoprionodon terraenovae) (Hoffmayer and Parsons, 2001), and the electric ray (T. marmorata) (Hughes and Johnston, '78) in response to hypoxia, and the nurse hound shark (Scyliorhinus stellaris) (Piiper et al., '72) and the dusky shark (Carcharhinus obscurus) (Cliff and Thurman, '84) after exhaustive exercise. These delayed peaks in lactate concentrations are attributed to slow lactate removal of poorly perfused tissues, such as white muscle fibres, due to vascular shunts and the reduction of circulation to the gut and peripheral tissue (Wells and Baldwin, '06).

\section{Conclusions}

In its natural environment, on coral reef flats the anoxia-tolerant epaulette shark is periodically and cyclically exposed to diminished oxygen. Previous studies have shown that the epaulette shark initially increases anaerobic metabolism on exposure to hypoxic 
preconditioning (Routley et al., 2002; Wise et al., '98) and subsequently enters into a state of neuronal metabolic depression (Mulvey and Renshaw, 2000; Renshaw et al., 2002).

In response to a standardised anoxic challenge, increases in haematocrit and plasma lactate occurred which paralleled increases in erythrocyte volume and anaerobic metabolism respectively. Significant increases in plasma lactate is a typical response to anoxic exposure in both teleosts and elasmobranch species, however lactate concentrations in the epaulette shark were the highest ever to be reported in an elasmobranch, indicating not only a high anaerobic capacity but also a high tolerance to the accumulation of metabolic end products such as lactate and associated acidosis. This study is the first report of a change in haematocrit due to erythrocyte swelling in response to anoxia followed by re-oxygenation in an elasmobranch species, the epaulette shark, which is of potential ecophysiological relevance because erythrocyte swelling assists oxygen offloading.

The grey carpet shark showed significant haematological responses to anoxic exposure that differed from the epaulette shark. This study is the first to demonstrate that the grey carpet shark can tolerate an extended anoxic challenge and to report a significant increase in $[\mathrm{RBC}]$ in any elasmobranch, immediately following anoxia. It is suggested that this increase in $[\mathrm{RBC}]$ may be due to a release of erythrocytes into the circulation, due to splenic contraction or a reduction of the blood supply to non vital organs and the musculature. Alternatively, it is possible that haemoconcentration alone or in combination with $\mathrm{RBC}$ release results in the significant increase in $\mathrm{RBC}$ concentration in grey carpet sharks in response to anoxic challenge. 
During anoxia, plasma lactate concentrations significantly increased in both species, indicating the up-regulation of anaerobic metabolism. Additionally, both species maintained plasma glucose concentrations, which indicate a very sensitive regulation of blood glucose levels. Following re-oxygenation, this study clearly shows for the first time, two elasmobranch species entering a phase of hyperglycaemia during normoxic re-oxygenation following anoxia. The hyperglycaemic state during re-oxygenation could potentially reflect an up-regulation of aerobic metabolism, which could serve to rapidly replenish ATP levels.

While these elasmobranch species are closely related, they demonstrate different ecophysiological adaptations that would confer an advantage during severe declines in oxygen availability. The epaulette shark significantly up regulates the level of anaerobic metabolism to generate ATP. In addition there was an increased RBC volume, which may increase oxygen unloading from the erythrocytes. Similarly, the increase in plasma lactate in the grey carpet shark indicates an up-regulation of anaerobic metabolism. In contrast to the epaulette shark, the grey carpet shark rapidly increased erythrocyte number in response to anoxic challenge, indicating a redirection of oxygen stores during periods of oxygen deficit. Both species demonstrate ecophysiologically relevant adaptations which may prolong survival in the intermittently hypoxic or even briefly anoxic environment encountered in tidal pools, mangrove swamps, and in some estuaries and coral reef environments. 


\section{ACKNOWLEDGEMENTS}

We would like to thank Andreas Fischer and UnderWater World (Sunshine Coast, Australia), Trevor Long and Marine Horton at Sea World (Gold Coast, Australia) for supplying animals. Acknowledge the help of the staff at Heron Island Research Station for facilitating the fieldwork and Blake Harahush for her assistance with experiments. 


\section{LITERATURE CITED}

Affonso EG, Polez VLP, Correa CF, Mazon AF, Araujo MRR, Moraes G, Rantin FT. 2002. Blood parameters and metabolites in the teleost fish Colossoma macropomum exposed to sulfide or hypoxia. Comp Biochem Physiol C 133:375-382.

Baker DW, Wood AM, Kieffer JD. 2005. Juvenile Atlantic and shortnose sturgeons (Family Acipenseridae) have different hematological responses to acute environmental hypoxia. Physiol Biochem Zool 78:916-925.

Baldwin J, Wells RMG. 1990. Oxygen transport potential in tropical elasmobranchs from the Great Barrier Reef: Relationship between haematology and blood viscosity. J Exp Mar Bio and Ecol 144:145-155.

Bourne PK. 1986. Changes in haematological parameters associated with capture and captivity of the marine teleost, Pleuronectes platessa L. Comp Biochem Physiol A $85: 435-43$.

Bracewell P, Cowx IG, Uglow RF. 2004. Effects of handling and electrofishing on plasma glucose and whole blood lactate of Leuciscus cephalus. J Fish Biol 64:65-71.

Butler P J, Taylor EW, Davison W. 1979. The effect of long term, moderate hypoxia on acid base balance, plasma catecholamines and possible anaerobic end products in the unrestrained dogfish Scyliorhinus canicula. J Comp Physiol B 132:297-303.

Carlson JK, Parsons GR. 2003. Respiratory and haematological responses of the bonnetthead shark, Sphyrna tiburo, to acute changes in dissolved oxygen. J Exp Mar Biol Ecol 294:15-26.

Chiocchia G, Motais R. 1989. Effect of catecholamine on deformability of red cells from trout: relative roles of cyclic AMP and cell volume. J Physiol (Paris) 412:321-332.

Chippari-Gomes AR, Gomes LC, Lopes NP, Val AL, Almeida-Val VMF. 2005. Metabolic adjustments in two Amazonian cichlids exposed to hypoxia and anoxia. Comp Biochem Physiol B 141:347-355.

Cliff G, Thurman GD. 1984. Pathological and physiological effects of stress during capture and transport in juvenile dusky shark, Carcharhinus obscurus. Comp Biochem. Physiol A 78:167-173.

Dick PT, Dixon DG. 1985. Changes in circulating blood cell levels of rainbow trout, Salmo gairdneri (Richardson), following acute and chronic exposure to copper. J Fish Biol 26:475-481. 
Fange R, Johansson-Sjobeck ML. 1975. The effect of splenectomy on the hematology and on the activity of delta-aminolevulinic acid dehydratase (ALA-D) in hemopoietic tissues of the dogfish, Scyliorhinus canicula (Elasmobranchii). Comp Biochem Physiol A 52:577-80.

Fievet B, Motais R, Thomas S. 1987. Role of adrenergic-dependent $\mathrm{H}^{+}$release from red cells in acidosis induced by hypoxia in trout. Am J Physiol 252:R269-275.

Fry FEJ. (1947). Effects of the environment on animal activity. University of Toronto Studies Biological Series No 55, Publication of the Ontario Fish Research Laboratory no 68:1-62.

Hall FG, Gray IE, Lepkovsky S. 1926. The influence of asphyxiation on the blood constituents of marine fishes. J Biol Chem 67:549-554.

Hardisty MW, Zelnik PR, Wright VC. 1976. The effects of hypoxia on blood sugar levels and on the endocrine pancreas, interrenal, and chromaffin tissues of the lamprey, Lampetry fluviatilis (L.). Gen Comp Endo 28:184-204.

Hoffmayer ER, Parsons GR. 2001. The physiological response to capture and handling stress in Atlantic sharpnose shark, Rhizoprionodon terraenovae. Fish Physiol Biochem 25:277-285.

Hughes GM, Johnston IA. 1978. Some responses of the electric ray (Torpedo marmorata) to low ambient oxygen tensions. J Exp Biol 73:107-117.

Jensen FB. 2004. Red blood cell pH, the Bohr effect, and other oxygenation-linked phenomena in blood $\mathrm{O}_{2}$ and $\mathrm{CO}_{2}$ transport. Act Physiol Scand 182:215-227.

Lai JC, Kakuta I, Mok HO, Rummer JL, Randall D. 2006. Effects of moderate and substantial hypoxia on erythropoietin levels in rainbow trout kidney and spleen. J Exp Biol 209:2734-8.

Last PR, Stevens JD. 1994. Sharks and Rays of Australia. CSIRO Division of Fisheries. Melbourne, Australia.

Lutz PL, Nilsson GE. 1997. Contrasting strategies for anoxic brain survival-glycolysis up or down. J Exp Biol 200:411-419.

Maccormack TJ, Lewis JM, Almeida-Val VM, Val AL, Driedzic WR. 2006. Carbohydrate management, anaerobic metabolism, and adenosine levels in the armoured catfish, Liposarcus pardalis (Castelnau), during hypoxia. J Exp Zool 305:363-75.

Martini, FF. 1974. Effects of capture and fasting confinement on an elasmobranch, Squalus acanthias. Unpublished Ph.D. Thesis, New York: Cornell University. 
McDonald DG, Milligan CL. 1992. Chemical properties of the blood. In: Hoar W.S., Randall DJ, Farrell AP, editors. Fish Physiology, XIIB. London: Academic Press, p 56-133.

Milligan CL, Wood CM. 1987. Regulation of blood oxygen transport and red cell pHi after exhaustive activity in rainbow trout (Salmo gairdneri) and starry flounder (Platichthys stellatus). J Exp Biol 133:263-282.

Montero D, Tort L, Robaina L, Vergara JM, Izquierdo MS. 2001. Low vitamin E in diet reduces stress resistance of gilthead seabream (Sparus aurata) juveniles. Fish \& Shellfish Immuno 11:473-490.

Mulvey JM, Renshaw GMC. 2000. Neuronal oxidative hypometabolism in the brainstem of the epaulette shark (Hemiscyllium ocellatum) in response to hypoxic pre-conditioning. Neuroscience Letters 290:1-4.

Nilsson S, Holmgren S, Grove DJ. 1975. Effects of drugs and nerve stimulation on the spleen and arteries of two species of dogfish, Scyliorhinus canicula and Squalus acanthias. Act Physiol Scand 95:219-30.

Opdyke DF, Opdyke NE. 1971. Splenic responses to stimulation in Squalus acanthias. Am J Physiol 221:623-625.

Pearson MP, Stevens ED. 1991. Size and hematological impact of the splenic erythrocyte reservoir in rainbow trout, Oncorhynchus mykiss. Fish Physiol Biochem 9:39-50.

Perry S, Gilmour K. 1996. Consequences of catecholamine release on ventilation and blood oxygen transport during hypoxia and hypercapnia in an elasmobranch Squalus acanthias and a teleost Oncorhynchus mykiss. J Exp Biol 199:2105-2118.

Piiper J, Baumgarten D. 1968. Analysis of brachial gaseous exchange in an elasmobranch fish: Scyliorhinus stellaris. J Physiol (Paris) 60:518.

Renshaw GMC, Dyson SE. 1999. Increased nitric oxide sythase in the vasculature of the epaulette shark brain following hypoxia. NeuroReport 10:1707-1712.

Renshaw, GMC, Kerrisk, CB, Nilsson, GE. 2002. The role of adenosine in the anoxic survival of the Epaulette shark, Hemiscyllium ocellatum. Comp Biochem Physiol B 131:133-141.

Renshaw GMC, Nikinmaa M. Oxygen sensors of the peripheral and central nervous system. 2007. In: D. Johnson, editor. Handbook of Neurochemistry and Molecular Neurobiology, 3rd edition, 20, Sensory Neurochemisty, Springer, New York, p 272296. 
Richmond JP, Burns JM, Rea LD, Mashburn, KL. 2005. Postnatal ontogeny of erythropoietin and hematology in free-ranging Steller sea lions (Eumetopias jubatus). Gen Comp Endo 141:240-247.

Routley MH, Nilsson GE, Renshaw GMC. 2002. Exposure to hypoxia primes the respiratory and metabolic responses of the Epaulette shark to progressive hypoxia. Comp Biochem Physiol A 131:313-321.

Salama A, Nikinmaa, M. 1990. Effect of oxygen tension on catecholamine-induced formation of cAMP and on swelling of carp red blood cells. Am J Physiol 259:C723-726.

Smith HW. 1931. The absorption and excretion of water and salts by the elasmobranch fishes. II Marine elasmobranchs. Am J Physiol 98:296-310.

Soderstrom V, Renshaw GMC, Nilsson GE. 1999. Brain blood flow and blood pressure during hypoxia in the Epaulette shark Hemiscyllium ocellatum, a Hypoxia-tolerant Elasmobranch. J Exp Biol 202:829-835.

Soivio A, Nikinmaa M, Westman K. 1980. The blood oxygen binding properties of hypoxic Salmo gairderi. J Comp Physiol 136:83-87.

Soivio A, Westman K, Nyholm K. 1974a. Changes in haematocrit values in blood samples treated with and without oxygen; a comparative study with four salmonid species. J Fish Biol 6:763.

Soivio A, Westman K, Nyholm K. 1974b. The influence of changes in oxygen tension on the haematocrit value of blood samples from asphyxic rainbow trout (Salmo gairdneri). Aqua 3:395-401.

Soldatov AA. 1996. The effect of hypoxia on red blood cells of flounder: a morphologic and autoadiographic study. J Fish Biol 48:321-328.

Stokes EE, Firkin BG. 2008. Studies of the Peripheral Blood of the Port Jackson Shark (Heterodontus portusjacksoni) with Particular Reference to the Thrombocyte. Br J Haematol. 1971 Apr;20(4):427-35

Stoskopf MK. 1993. Clinical pathology. In fish medicine. W.B. Saunders, Philadelphia $882 \mathrm{pp}$.

Stoskopf MK, Smith B, Klay G. 1984. Clinical note: Blood sampling of captive sharks. J Zool Anat Med 15:116-117.

Swift DJ, Lloyd R. 1974. Changes in urine flow rate and haematocrit value of rainbow trout Salmo gairdneri (Richardson) exposed to hypoxia. J. Fish Biol. 6:379-387. 
Tetens V, Lykkeboe G. 1981. Blood respiratory properties of rainbow trout, Salmo gairdneri: Responses to hypoxia acclimation and anoxic incubation of blood in vitro. J Comp Physiol B 145:117-125.

Thomas S, Fievet B, Motais R. 1986. Effect of deep hypoxia on acid-base balance in trout: role of ion transfer processes. Am J Physiol Regul Integr Comp Physiol 250:R319R327

Thomas S, Hughes GM. 1982a. Effects of hypoxia on blood gas and acid-base parameters of sea bass. J Appl Physiol 53:1336-1341.

Thomas S, Hughes, GM. 1982b. A study of the effects of hypoxia on acid-base status of rainbow trout blood using an extracorporeal blood circulation. Resp Physiol 49:37182.

Thorson T B, Gerst JW. 1973. Comparison of some parameters of serum and uterine fluid of pregnant, vivparous sharks (Carcharhinus leucas) and serum of their near-term young. Comp Biochem Physiol A 42:33-40.

Tufts BL, Randall DJ. 1989. The functional significance of adrenergic $\mathrm{pH}$ regulation in fish erythrocytes. Can J Zool 67:235-238.

Virani NA, Rees BB. 2000. Oxygen consumption, blood lactate and inter-individual variation in the gulf killifish, Fundulus grandis, during hypoxia and recovery. Comp Biochem Physiol A 126:397-405.

Waring CP, Stag RM, Poxton MG. 1992. The effects of handling on flounder (Platichthys flesus L) and Atlantic Salmon (Salmo salar L). J Fish Biol 41:131-144.

Wells RMG, Baldwin J. 2006. Plasma lactate and glucose flushes following burst swimming in silver trevally (Pseudocaranx dentex: Carangidae) support the "releaser" hypothesis. Comp Biochem Physiol A 143:347-352.

Wise G, Mulvey JM, Renshaw GMC. 1998. Hypoxia Tolerance in the Epaulette Shark (Hemiscyllium ocellatum). J Exp Zool 281, 1-5.

Wood CM, Perry SF, Walsh PJ, Thomas S. 1994. HCO ${ }^{3-}$ dehydration by the blood of an elasmobranch in the absence of a Haldane effect. Resp Physiol 98:319-37.

Wright PA, Perry SF, Moon TW. 1989. Regulation of hepatic glucogenesis and glycogenolysis by catecholamines in rainbow trout during environmental hypoxia. J. Exp. Biol. 147:169-188.

Yamamoto K. 1987. Contraction of spleen in exercised cyprinid. Comp Biochem Physiol A $87: 1087-7$. 
Yamamoto K, Itazawa Y, Kobayashi H. 1983. Erythrocyte supply from the spleen and hemoconcentration in hypoxic yellowtail. Mar Biol 73:221-226. 
Table 1. Erythrocyte indices calculated for the Epaulette shark (Hemiscyllium ocellatum).

\begin{tabular}{|c|c|c|c|c|c|c|c|c|c|c|c|}
\hline \multirow{5}{*}{ Anoxia } & & \multicolumn{5}{|c|}{ Captive } & \multicolumn{5}{|l|}{ Wild } \\
\hline & & Pre & Post & $2 \mathrm{Hrs}$ & $6 \mathrm{Hrs}$ & $12 \mathrm{Hrs}$ & Pre & Post & $2 \mathrm{Hrs}$ & $6 \mathrm{Hrs}$ & $12 \mathrm{Hrs}$ \\
\hline & $\begin{array}{l}\mathrm{MCV} \\
\left(f_{\mathrm{L}}\right)\end{array}$ & $\begin{array}{l}556.5 \\
(37)\end{array}$ & $\begin{array}{l}669.4 \\
(84)^{*}\end{array}$ & $\begin{array}{l}663.7 \\
(62)^{\dagger}\end{array}$ & $\begin{array}{l}563.8 \\
(46)\end{array}$ & $\begin{array}{l}525.7 \\
(67)\end{array}$ & $\begin{array}{l}620.6 \\
(60)\end{array}$ & $\begin{array}{l}772 \\
(48)\end{array}$ & $\begin{array}{l}799.4 \\
(80)\end{array}$ & $\begin{array}{l}688.3 \\
(55)\end{array}$ & $\begin{array}{l}675.4 \\
(43)\end{array}$ \\
\hline & $\mathrm{MCH}$ & $\begin{array}{l}155 \\
(15)\end{array}$ & $\begin{array}{l}157.9 \\
(10)\end{array}$ & $\begin{array}{l}155.2 \\
(19)\end{array}$ & $\begin{array}{l}159.9 \\
(25)\end{array}$ & $\begin{array}{l}157.9 \\
(13)\end{array}$ & $\begin{array}{l}171.7 \\
(30)\end{array}$ & $167(9)$ & $\begin{array}{l}183.6 \\
(24)\end{array}$ & $\begin{array}{l}181.7 \\
(19)\end{array}$ & $\begin{array}{l}173 \\
(15)\end{array}$ \\
\hline & $\begin{array}{l}\mathrm{MCHC} \\
\left(\mathrm{g} \mathrm{dL}^{-1}\right)\end{array}$ & $\begin{array}{l}27.9 \\
(2)\end{array}$ & $\begin{array}{l}23.8 \\
(2)^{*}\end{array}$ & $\begin{array}{l}23.4 \\
(2)^{\dagger}\end{array}$ & $\begin{array}{l}27.1 \\
(1)\end{array}$ & $\begin{array}{l}26.4 \\
(3)\end{array}$ & $28.4(2)$ & $21.7(2)$ & $22.9(2)$ & $27.5(2)$ & $28.0(2)$ \\
\hline \multirow[t]{2}{*}{ Control } & $\begin{array}{l}\text { MCV } \\
\left(f_{\mathrm{L}}\right) \\
\mathrm{MCH}\end{array}$ & $\begin{array}{l}583.7 \\
(109) \\
166.7 \\
(33)\end{array}$ & $\begin{array}{l}524.5 \\
(41) \\
148.4 \\
(19)\end{array}$ & $\begin{array}{l}632.3 \\
(41) \\
171.2 \\
(15)\end{array}$ & $\begin{array}{l}630.5 \\
(50) \\
167 \\
(11)\end{array}$ & $\begin{array}{l}636.5 \\
(74) \\
163.3 \\
(22)\end{array}$ & $\begin{array}{l}722.7 \\
(85) \\
197.3 \\
(21)\end{array}$ & $\begin{array}{l}649 \\
(61) \\
180.3 \\
(12)\end{array}$ & $\begin{array}{l}632.7 \\
(49) \\
174.6 \\
(30)\end{array}$ & $\begin{array}{l}688.1 \\
(8) \\
214.8 \\
(13)\end{array}$ & $\begin{array}{l}645.6 \\
(92) \\
188.1 \\
(6)\end{array}$ \\
\hline & $\begin{array}{l}\mathrm{MCHC} \\
\left(\mathrm{g} \mathrm{dL}^{-1}\right)\end{array}$ & $\begin{array}{l}28.5 \\
\text { (1) }\end{array}$ & $\begin{array}{l}28.2 \\
(2)\end{array}$ & $\begin{array}{l}27.1 \\
\text { (1) }\end{array}$ & $\begin{array}{l}26.5 \\
(2)\end{array}$ & $\begin{array}{l}25.7 \\
(3)\end{array}$ & 27.4 (3) & $27.8(1)$ & 27.5 (4) & $31.2(2)$ & $29.5(3)$ \\
\hline
\end{tabular}

Erythrocytic indices: mean corpuscular volume (MCV), mean corpuscular haemoglobin (MCH) and mean corpuscular haemoglobin concentration (MCHC) calculated for captive $(n=9)$ and wild $(n=10)$ epaulette sharks, pre- and post-anoxic challenge and during 12 hours of normoxic re-oxygenation. The figure in brackets () is the standard deviation.

Table 2. Erythrocyte indices calculated for the Grey carpet shark (Chiloscyllium punctatum).

\begin{tabular}{|c|c|c|c|c|c|c|c|c|c|c|c|}
\hline \multirow{5}{*}{ Anoxia } & & \multicolumn{5}{|c|}{ Captive } & \multicolumn{5}{|l|}{ Wild } \\
\hline & & Pre & Post & $2 \mathrm{Hrs}$ & $6 \mathrm{Hrs}$ & $12 \mathrm{Hrs}$ & Pre & Post & $2 \mathrm{Hrs}$ & $6 \mathrm{Hrs}$ & $12 \mathrm{Hrs}$ \\
\hline & $\mathrm{MCV}$ & $\begin{array}{l}666.3 \\
(103)\end{array}$ & $\begin{array}{l}626 \\
(52)\end{array}$ & $\begin{array}{l}691.8 \\
(78)\end{array}$ & $\begin{array}{l}651.8 \\
(97)\end{array}$ & $\begin{array}{l}699.6 \\
(91)\end{array}$ & $\begin{array}{l}910.8 \\
(118)\end{array}$ & $\begin{array}{l}809.5 \\
(109)\end{array}$ & $\begin{array}{l}877.2 \\
(56)\end{array}$ & $\begin{array}{l}930 \\
(60)\end{array}$ & $\begin{array}{l}941.9 \\
(50)\end{array}$ \\
\hline & $\mathrm{MCH}$ & $\begin{array}{l}200.8 \\
(29)\end{array}$ & $\begin{array}{l}195.1 \\
(25)\end{array}$ & $\begin{array}{l}196.1 \\
(14)\end{array}$ & $\begin{array}{l}202.2 \\
(28)\end{array}$ & $\begin{array}{l}211.2 \\
(28)\end{array}$ & $\begin{array}{l}246.2 \\
(23)\end{array}$ & $\begin{array}{l}225.6 \\
(25)\end{array}$ & $\begin{array}{l}241 \\
(12)\end{array}$ & $\begin{array}{l}255.6 \\
(33)\end{array}$ & $\begin{array}{l}242.9 \\
(22)\end{array}$ \\
\hline & $\begin{array}{l}\mathrm{MCHC} \\
\left(\mathrm{g} \mathrm{L}^{-1}\right)\end{array}$ & $\begin{array}{l}30.3 \\
\text { (3) }\end{array}$ & $\begin{array}{l}31.2 \\
\text { (3) }\end{array}$ & $\begin{array}{l}28.5 \\
(2)\end{array}$ & $\begin{array}{l}31.1 \\
(2)\end{array}$ & $\begin{array}{l}30.2 \\
(2)\end{array}$ & $27.1(1)$ & $27.9(1)$ & $27.5(2)$ & $27.7(2)$ & $25.7(3)$ \\
\hline \multirow[t]{3}{*}{ Control } & $\begin{array}{l}\mathrm{MCV} \\
\left(f_{\mathrm{L}}\right)\end{array}$ & $\begin{array}{l}686.2 \\
(82)\end{array}$ & $\begin{array}{l}687.9 \\
(96)\end{array}$ & $\begin{array}{l}669.3 \\
(74)\end{array}$ & $\begin{array}{l}687.6 \\
(57)\end{array}$ & $\begin{array}{l}643 \\
(59)\end{array}$ & $\begin{array}{l}917.4 \\
(40)\end{array}$ & $\begin{array}{l}923.5 \\
(50)\end{array}$ & $\begin{array}{l}997 \\
(143)\end{array}$ & $\begin{array}{l}941.3 \\
(49)\end{array}$ & $\begin{array}{l}953.5 \\
(122)\end{array}$ \\
\hline & $\mathrm{MCH}$ & $\begin{array}{l}204.7 \\
(10)\end{array}$ & $\begin{array}{l}196.3 \\
(13)\end{array}$ & $\begin{array}{l}190.9 \\
(13)\end{array}$ & $\begin{array}{l}202.1 \\
(21)\end{array}$ & $\begin{array}{l}203.4 \\
(25)\end{array}$ & $\begin{array}{l}254.9 \\
(13)\end{array}$ & $\begin{array}{l}245.2 \\
\text { (21) }\end{array}$ & $\begin{array}{l}274.6 \\
(33)\end{array}$ & $\begin{array}{l}252.5 \\
(7)\end{array}$ & $\begin{array}{l}251.2 \\
(37)\end{array}$ \\
\hline & $\begin{array}{l}\mathrm{MCHC} \\
\left(\mathrm{g} \mathrm{L}^{-1}\right)\end{array}$ & $30(2)$ & $\begin{array}{l}28.8 \\
\text { (3) }\end{array}$ & $\begin{array}{l}28.7 \\
\text { (3) }\end{array}$ & $\begin{array}{l}29.4 \\
\text { (1) }\end{array}$ & $\begin{array}{l}31.6 \\
\text { (1) }\end{array}$ & $27.8(1)$ & $26.5(2)$ & $27.6(1)$ & $26.9(1)$ & $26.3(1)$ \\
\hline
\end{tabular}

Erythrocytic indices: mean corpuscular volume (MCV), mean corpuscular haemoglobin (MCH) and mean corpuscular haemoglobin concentration $(\mathrm{MCHC})$ calculated for captive $(\mathrm{n}=9)$ and wild $(\mathrm{n}=6)$ grey carpet sharks, pre- and post-anoxic challenge and during 12 hours of normoxic re-oxygenation. The figure in brackets () is the standard deviation 


\section{Figure legends.}

Figure 1A. Mean haematocrit values for epaulette sharks and grey carpet sharks in two different environments, held in normoxia (controls). Transfer 1 corresponds to the time period that experimental animals were in anoxia and transfer 2 corresponds to the time course of reoxygenation in normoxia for experimental animals. The symbol * indicates a significantly higher initial value compared to captive sharks. No significant changes were observed within control groups at any of the sample times.

Figure 1B. Mean haematocrit values for the epaulette shark and the grey carpet shark before and immediately following 1.5 hours of anoxia and at 2 hours, 6 hours and 12 hours of reoxygenation in normoxia. No significant changes were observed in any of the control groups. The symbols indicate significant differences compared to the mean * pre-experiment or $\uparrow$ at 2 hours following anoxic challenge.

Figure 2. Mean red blood cell counts for the epaulette shark and the grey carpet shark before and immediately following 1.5 hours of anoxia and at 2 hours, 6 hours and 12 hours of reoxygenation in normoxia. No significant changes were observed in any of the control groups. Symbols indicate significant differences compared to the mean * pre-experiment or $\dagger$ at 2 hours following anoxic challenge.

\section{Figure 3A.}

Mean haemoglobin for epaulette sharks and grey carpet sharks in two different environments, held in normoxia (controls). Transfer 1 corresponds to the time period that experimental animals were in anoxia and transfer 2 corresponds to the time course of reoxygenation in 
normoxia for experimental animals. The symbol * indicates a significantly higher initial value compared to captive sharks. No significant changes were observed within control groups at any of the sample times.

Figure 3B. Mean haemoglobin for the epaulette shark and the grey carpet shark before and immediately following 1.5 hours of anoxia and at 2 hours, 6 hours and 12 hours of reoxygenation in normoxia. No significant changes were observed in any of the control groups. Symbols indicate significant differences compared to the mean $*$ pre-experiment or $\dagger$ at 2 hours following anoxic challenge.

Figure 4. Mean plasma glucose for the epaulette shark and the grey carpet shark before and immediately following 1.5 hours of anoxia and at 2 hours, 6 hours and 12 hours of reoxygenation in normoxia. No significant changes were observed in any of the control groups. Symbols indicate significant differences compared to the mean $*$ pre-experiment, $\dagger$ at 2 hours, \#6 hours, or $\times 12$ hours following anoxic challenge.

Figure 5A. Mean plasma lactate for epaulette sharks and grey carpet sharks in two different environments, held in normoxia (controls). Transfer 1 corresponds to the time period that experimental animals were in anoxia and transfer 2 corresponds to the time course of reoxygenation in normoxia for experimental animals. Symbols indicate significant differences compared to the mean * pre-normoxic transfer 2 and $\uparrow$ at 2 hours after transfer 2 .

Figure 5B. Mean plasma lactate of the epaulette shark and the grey carpet shark. Mean plasma lactate concentrations before and immediately following 1.5 hours of anoxia and at 2 hours, 6 hours and 12 hours of re-oxygenation in normoxia. Symbols indicate significant 
differences compared to the mean * pre-experiment, $\uparrow$ at 2 hours, \# 6 hours, or $\times 12$ hours following anoxic challenge. 
Figure 1A. Mean haematocrit values for epaulette sharks and grey carpet sharks in two different environments, held in normoxia (controls). Transfer 1 corresponds to the time period that experimental animals were in anoxia and transfer 2 corresponds to the time course of reoxygenation in normoxia for experimental animals. The symbol * indicates a significantly higher initial value compared to captive sharks. No significant changes were observed within control groups at any of the sample times.

$297 \times 209 \mathrm{~mm}(300 \times 300 \mathrm{DPI})$ 
1

2

3

4

5

6

7

8

9

10

11

12

13

14

15

16

17

18

19

20

21

22

23

24

25

26

27

28

29

30

31

32

33

34

35

36

37

38

39

40

41

42

43

44

45

46

47

48

49

50

51

52

53

54

55

56

57

58

59

60

Figure 1B

B Changes in percent haematocrit in response to anoxic challenge and reoxygenation in two species of sharks from two environments.

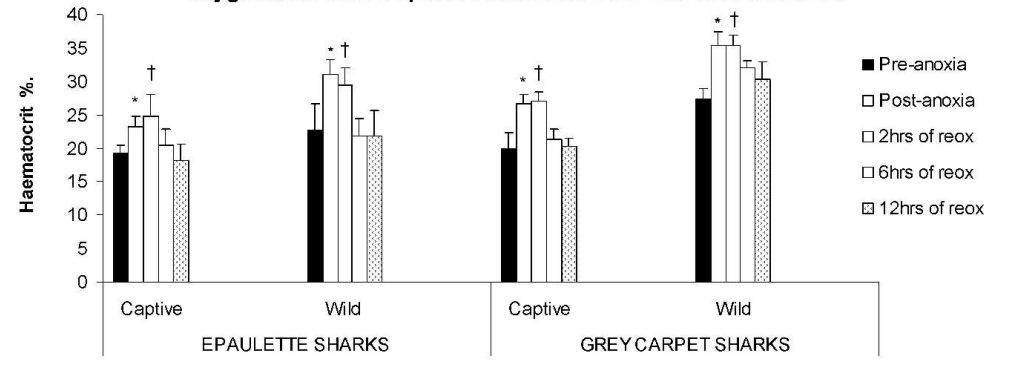

Figure 1B. Mean haematocrit values for (a) the epaulette shark and (b) the grey carpet shark before and immediately following 1.5 hours of anoxia and at 2 hours, 6 hours and 12 hours of reoxygenation in normoxia. No significant changes were observed in any of the control groups. The symbols indicate significant differences compared to the mean * pre-experiment or $t$ at 2 hours following anoxic challenge.

$297 \times 209 \mathrm{~mm}(300 \times 300$ DPI) 
Figure 2. Mean red blood cell counts for the epaulette shark and the grey carpet shark before and immediately following 1.5 hours of anoxia and at 2 hours, 6 hours and 12 hours of re-oxygenation in normoxia. No significant changes were observed in any of the control groups. Symbols indicate significant differences compared to the mean * pre-experiment or $\dagger$ at 2 hours following anoxic challenge.

$297 \times 209 \mathrm{~mm}(300 \times 300$ DPI $)$ 
1

2

3

4

5

6

7

8

9

10

11

12

13

14

15

16

17

18

19

20

21

22

23

24

25

26

27

28

29

30

31

32

33

34

35

36

37

38

39

40

41

42

43

44

45

46

47

48

49

50

51

52

53

54

55

56

57

58

59

60
Figure 3A

A Haemoglobin concentration for control animals in two species of sharks

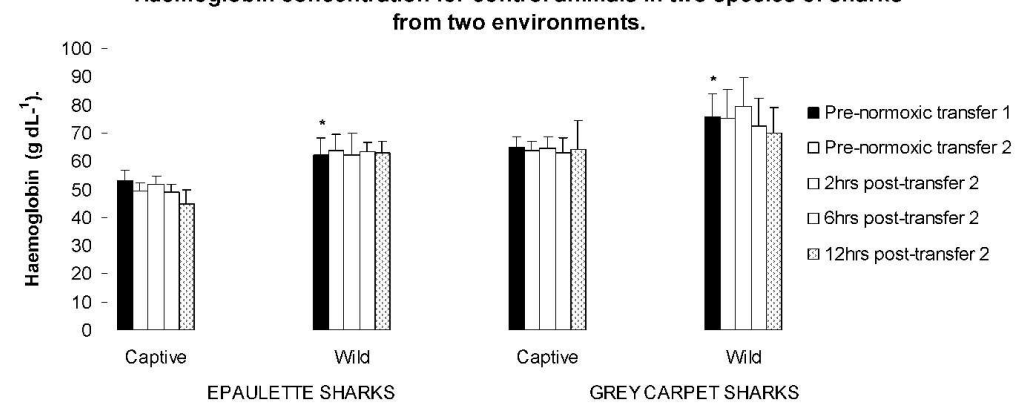

Figure 3A. Mean haemoglobin for epaulette sharks and grey carpet sharks in two different environments, held in normoxia (controls). Transfer 1 corresponds to the time period that experimental animals were in anoxia and transfer 2 corresponds to the time course of reoxygenation in normoxia for experimental animals. The symbol * indicates a significantly higher initial value compared to captive sharks. No significant changes were observed within control groups at any of the sample times.

$297 \times 209 \mathrm{~mm}(300 \times 300$ DPI $)$ 
Figure 3B. Mean haemoglobin for (a) the epaulette shark and (b) the grey carpet shark before and immediately following 1.5 hours of anoxia and at 2 hours, 6 hours and 12 hours of re-oxygenation in normoxia. No significant changes were observed in any of the control groups. Symbols indicate significant differences compared to the mean * pre-experiment or $\dagger$ at 2 hours following anoxic challenge.

$297 \times 209 \mathrm{~mm}(300 \times 300$ DPI $)$ 
Figure 4. Mean plasma glucose for the epaulette shark and the grey carpet shark before and immediately following 1.5 hours of anoxia and at 2 hours, 6 hours and 12 hours of re-oxygenation in normoxia. No significant changes were observed in any of the control groups. Symbols indicate significant differences compared to the mean * pre-experiment, $\dagger$ at 2 hours, \#6 hours, or $\times 12$ hours following anoxic challenge. $297 \times 209 \mathrm{~mm}(300 \times 300 \mathrm{DPI})$ 
Figure 5A. Mean plasma lactate for epaulette sharks and grey carpet sharks in two different environments, held in normoxia (controls). Transfer 1 corresponds to the time period that experimental animals were in anoxia and transfer 2 corresponds to the time course of reoxygenation in normoxia for experimental animals. Symbols indicate significant differences compared to the mean * pre-normoxic transfer 2 and $\dagger$ at 2 hours after transfer 2 . $297 \times 209 \mathrm{~mm}(300 \times 300$ DPI $)$ 
1

2

3

4

5

6

7

8

9

10

11

12

13

14

15

16

17

18

19

20

21

22

23

24

25

26

27

28

29

30

31

32

33

34

35

36

37

38

39

40

41

42

43

44

45

46

47

48

49

50

51

52

53

54

55

56

57

58

59

60
Figure 5B

B Changes in plasma lacatate concentration in response to anoxia and reogygenation for two species of sharks from two environments.

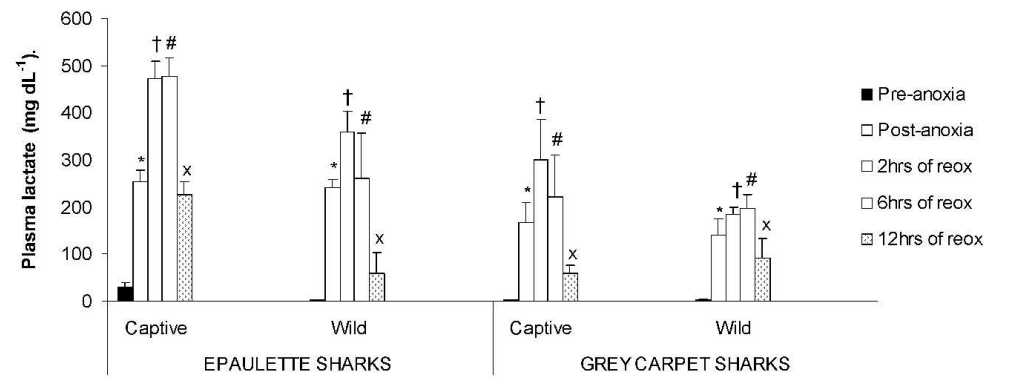

Figure 5B. Mean plasma lactate of the (a) epaulette shark and the (b) grey carpet shark. Mean plasma lactate concentrations before and immediately following 1.5 hours of anoxia and at 2 hours, 6 hours and 12 hours of re-oxygenation in normoxia. Symbols indicate significant differences compared to the mean * pre-experiment, $\dagger$ at 2 hours, \# 6 hours, or $\times 12$ hours following anoxic challenge.

297x209mm (300 x 300 DPI) 